\title{
MECHANICAL, STRUCTURAL AND DYNAMIC CHARACTERISATION OF WATER AGED COMPOSITE MARINE PROPELLER
}

\author{
D. HARSHA VARDHAN ${ }^{1 *}$, DR. A. RAMESH ${ }^{2} \&$ DR. B. CHANDRA MOHANA REDDY ${ }^{3}$ \\ ${ }^{I}$ Scholar, Department of Mechanical Engineering, JNTUA College of Engineering, Anantapuramu, Andhra Pradesh, India \\ ${ }^{2}$ Professor \& Principal, BIT Institute of Technology, Hindupur, Anantapuramu, Andhra Pradesh, India \\ ${ }^{3}$ Associate Professor \& H.O.D, Department of Mechanical Engineering, JNTUA College of Engineering, Anantapuramu,
}

Andhra Pradesh, India

\begin{abstract}
Marine propeller is the device which has to spend more of its life span under water. Recent studies shows that glass fibre Reinforced polymer (GFRP) composite material can be used to make marine propeller. On the other hand composite material properties were changing when exposed to water environment. In present work GFRP composite materials prepared by hand layup technique. Samples are subjected ageing with saline water (equivalent to sea water) for 15 days, 30 days and 45days, water uptake pattern was recorded as per ASTM D570. Unexposed GFRP and Aged GFRP samples were tested as per ASTM D638. Static structural and free vibration analysis carried on composite marine propeller using Optistruct solver with obtained mechanical properties. The results revealed that water ageing show much impact on the tensile strength than modulus. FEA results shows that the water ageing showing very little impact on displacement and vibration behaviour of composite marine propeller.

KEYWORDS: Marine Propeller, Composite Material, Water Ageing, FE Analysis \& Free Vibration
\end{abstract}

Received: Jun 08, 2020; Accepted: Jun 28, 2020; Published: Sep 15, 2020; Paper Id.: IJMPERDJUN20201238

\section{INTRODUCTION}

Various researchers are working over a period of time in order to develop a supplement material for marine Propeller to reduce failures in working conditions composite materials are generally used to the hulls of boats and yachts excluding massive vessels. Recently, the studies of marine propellers are focused on the application of composite materials[1]. On the other side, researchers said that the composite materials have an ageing effect with the water environment. Fibreglass reinforced bidirectional polymer composites are widely used in many industrial applications due to various advantages such as low weight, ease of processing, price suspension and noise. [2][3].With the sea water ageing there is significant drop in tensile strength with increase in ageing period [4]. The water uptake is by the composite is following fickian diffusion model, with the ageing strength and stiffness reduces[5]. sea water aging shows the impact on the fatigue strength and reduces the life of GFRP composite [6]. Water ageing caused to reduction flexural strength of composites made of vinyl ester/Glass by 20\%[7]. Water uptake also shows significant impact on fracture toughness causes to failure at early loads[8]

To analyse the ship propeller by using laws of similarity scaled model is generated to reduce the computation time in fluid dynamics and finite element simulations[9]. Openprop MAT LAB based tool used to analyse the open water characteristics and generate the propeller model. [10]. Recent days researchers focused on the GFRP composite material for marine propeller S .S. Raj et al. [11]carried out a dynamic simulation study, Y. S. Rao et al. [12]performed harmonic analysis, B.G. Paik et al. [13] experimentally investigated acoustic performance, 
Pieter Maljaars et al. [14] studies open water characteristics. studies carried structural model analysis to analyse the material impact on the propeller performance [15]-[17].

After reviewing the literature the present work is carried to analyse the impact of saline water aging on marine propeller made of GFRP composite material. For that composite material fabricated and subjected to aging for 15, 30 and 45 days in saline water. Composite Properties were extracted applied to marine propeller in Finite Element Analysis (FEA).

\section{MATERIALS AND METHODOLOGY}

To prepare the composite materials the combination of materials are used as shown in table 1 . The materials are obtained from sree industrial composite, Hyderabad.

\subsection{Manufacturing}

The Composites are made by hand Layup Technique. Epoxy (LY 556) and hardener (HY 951) were taken at a 90:10 weight ratio, mixed well with a mechanical stirrer. Part of the mix is poured into a precast form of 200 Sq.mm with $3 \mathrm{~mm}$. then the fibres are placed in position and the rest is poured into the mould. Composite materials allowed curing for 24 hours under load. Mould Release Spray used to easily remove material from the mould after composite lamination[18], samples prepared in accordance with ASTM D638[19].

Table 1: Materials used for Specimen Preparation

\begin{tabular}{|c|c|c|c|c|}
\hline S. No & Specimen & Fiber & Matrix & Saline water Ageing \\
\hline 1 & $\mathrm{C} 1$ & \multirow{4}{*}{ Woven Glass } & \multirow{4}{*}{$\begin{array}{l}\text { Epoxy(LY 556) } \\
+ \\
\text { Hardener (HY 951) }\end{array}$} & - \\
\hline 2 & $\mathrm{C} 2$ & & & 15 days \\
\hline 3 & $\mathrm{C} 3$ & & & 30 Days \\
\hline 4 & $\mathrm{C} 4$ & & & 45 Days \\
\hline
\end{tabular}

\subsection{Testing}

Tensile tests are carried on aged composite materials as per the ASTM standards and compared the results with plain GFRP properties. Samples are soaked for 15,30 and 45 days in water wth3.5\% salinity (Equivalent to sea water). The test is performed with a crosshead speed of $2 \mathrm{~mm} / \mathrm{min}$ and $50 \mathrm{KN}$ load cell on Universal Testing Machine (UTM) supplied by Instron.

\subsection{Propeller FE Modelling}

Propeller was modelled by using section curves generated by OpenProp as explained in our previously published work[20]. The torque and thrust forces obtained from open water characteristics are applied on propeller at $0.7 \mathrm{R}$ to analyze structural behavior. Bottom of the blade is constrained in all directions for structural and model analysis. Propeller blade is meshed with quadrilateral elements and 14 layers of composite is modelled based on thickness and width.

\section{RESULTS AND DISCUSSIONS}

\subsection{Water Uptake}

Ageing is carried according to ASTM D570. Samples are initially dried in the oven for 24hours at 50 degrees. Immersed samples are weighted for every 24 hours by removing from water and wiping with tissue paper. The weight of the samples recorded and the percentage of increase in weight is calculated by using the following relation. The average value of 3 specimens were plotted in following image. 


$$
\text { water uptake } \%=\frac{w_{1}-w_{0}}{w_{0}} X 100
$$

Where:

$\mathrm{W}_{1}=$ weight of the sample after immersion (Grams)

$\mathrm{W}_{0}=$ Initial weight of the samples (Grams)

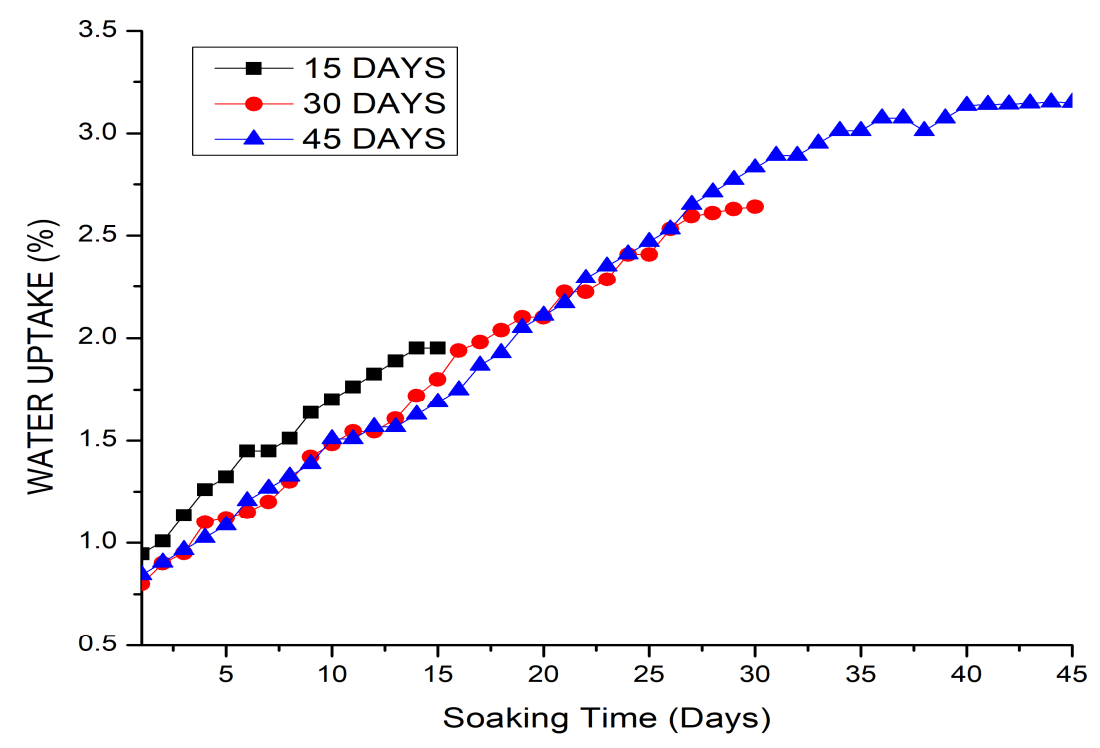

Figure 1: Water Uptake Pattern of GFRP Composite Material.

The figure 1 represents the amount of water uptake for the samples soaked in 15 days, 30 days and 45 days. The amount of water uptake increased with increase in soaking duration. The soaking duration has much influence on water uptake. The results pattern agreeing the Fick's law. The uptake pattern is found similar to the recent research on composite materials water ageing [4], [6], [7], [21]-[24]. It is known from the literature that glass fibre composites in distilled water reach the saturation usually in two or three months [25], the present study limited to1.5 months only, hence water uptake not reached to saturation stage. The change of specimen weight is apparent. 


\subsection{Mechanical Characterization}

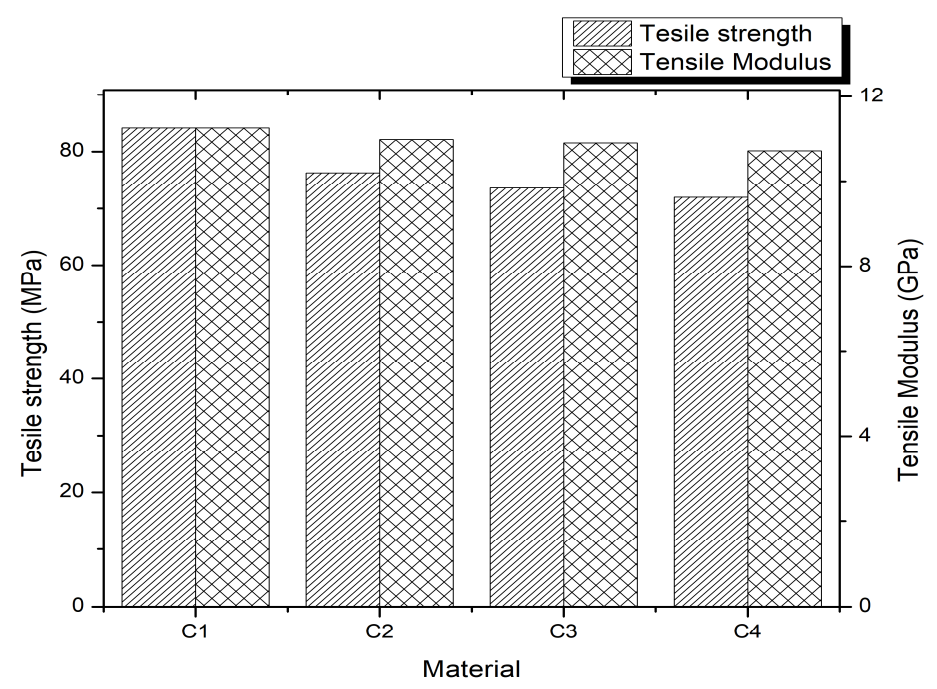

Figure 2: Tensile Strength and Modulus of GFRP Composite Material.

The water ageing influenced the strengths and modulus of glass fibre reinforced composites in tensile and flexural loading condition, as shown in the figure 2. Initially, glass fibre has the tensile strength $84.14 \mathrm{MPa}$ and tensile modulus of 11.254GPa. For samples aged in 3.5\% salinity tensile strength decreased by $9.3 \%, 12.5 \%$ and $14.5 \%$. Similarly, modulus decreed by $2.4 \%, 3.1 \%$ and $4.7 \%$ for 15,30 and 45 days respectively. However, the modulus is not reduced as much as strength. The strength tensile strength of GFRP composite has found reducing with an increase in soaking time.

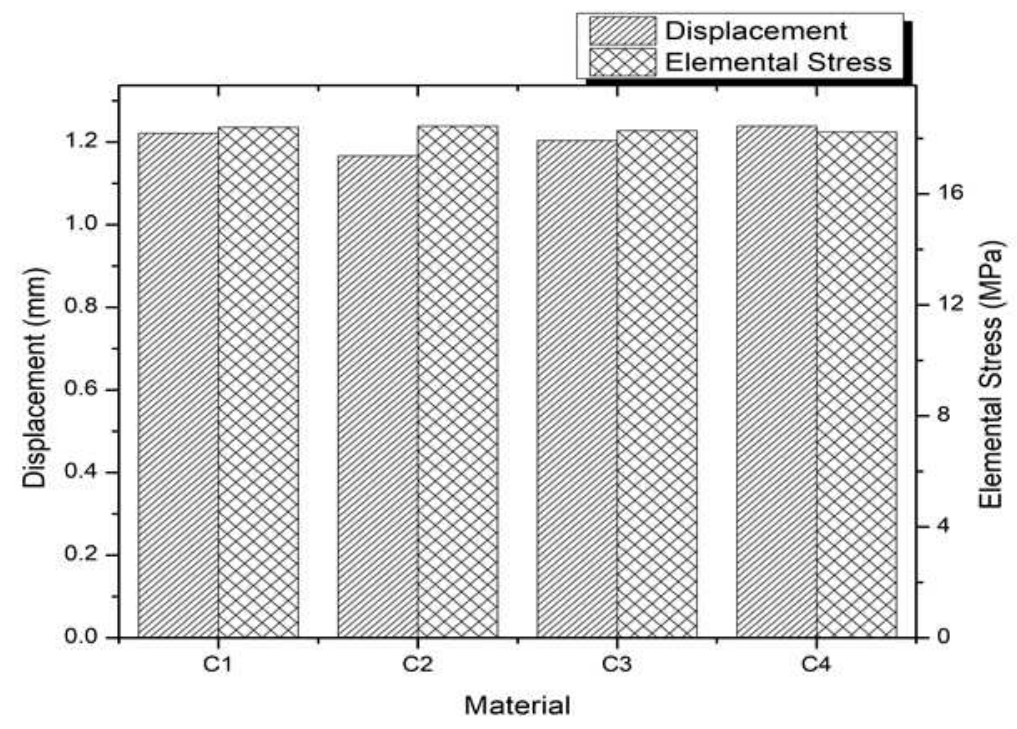

Figure 3: Composite Marine Propeller Displacement and Elemental Stress of Aged Propeller.

From the results, it is apparent that mechanical properties of GFRP composites are degrading to a great extent with an increase in soaking time. Form the recent research, and it is identified that "The interfacial damage resulting from the action of seawater could be observed in case of glass-epoxy composites. It appears that these composites have experienced some form of irreversible chemical degradation in the interfacial region. The onset of degradation can be witnessed by a longer length of fibre pull-outs and deboning between the fibre and matrix material. These symptoms of 
degradation are mostly due to the hydrolysis of polymeric material activated by the saline environment and breakdown of chemical bonds at the interface. Therefore, it is apparent that the glass-epoxy composites exhibited a reduction in mechanical properties"[23]. Similar results of degradation of mechanical properties due to water immersion of glass epoxy composite were reported in earlier studies [3], [5]. Form long term soaking the earlier studies reported that the diffusion of seawater into the composite materials has a particularly severe effect on static mechanical strength characteristics. A decrease of $20 \%$ to $40 \%$ in failure strengths were measured, but no significant effects on the elastic moduli have been observed. While extrapolation of mechanical test data to longer times may then be conservative [21].

\subsection{Transient Behavior of Marine Propeller}
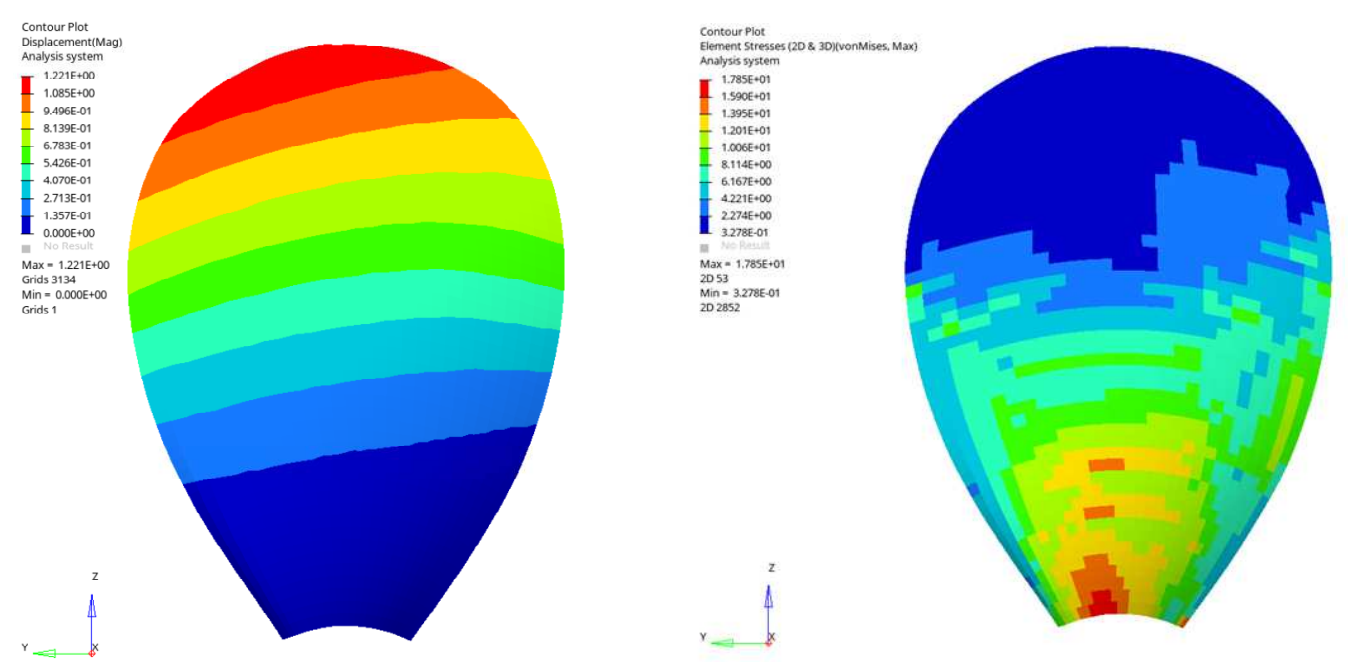

Figure 4: Before Ageing Composite Marine Propeller Displacement and Stress Distribution.

Transient behaviour of marine propeller analysed with FE simulation using Hypermesh with Optistruct solver. Soaked composite Material properties used to analyse the soaking effect on structural and vibration behaviour of marine propeller blade. The structural and vibration analysis were carries and results presented here.

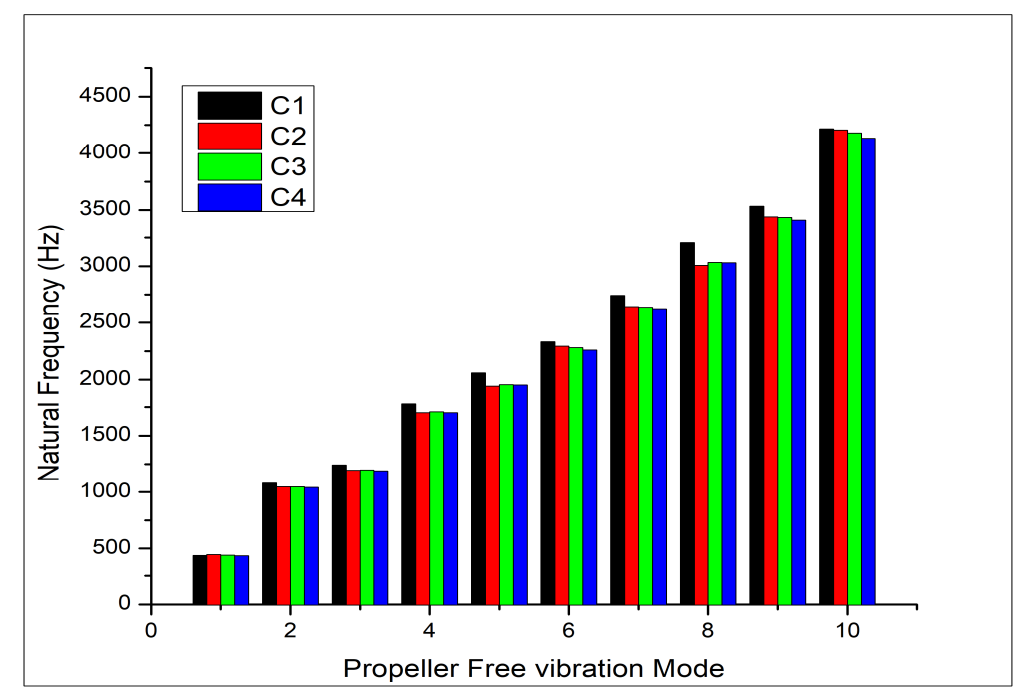

Figure 5: First 10 Natural Frequencies of Aged Composite Marine Propeller. 
The displacement of the propeller increasing with an increase in soaking time, initially for 15 days of soaking water found that reduction in displacement then with an increase in immersion time the tip displacement is increasing for GFRP propeller. With an increase in soaking duration, the propeller tip displacement was increasing as shown in Figure3. The displacement and stress distribution of un aged composite shown in figure 4. Similar distribution pattern is found after soaking with slight change in displacement value. Maximum displacement of the propeller is crucial parameter while selecting the propeller. The more displacement of the propeller will cause to reduction in propulsion efficiency [32][33][35].

Free vibration analysis on composite marine propeller carried. First ten natural frequencies of soaked GFRP marine propeller blade were extracted and compared with un-soaked propeller blade vibrations as shown in figure 5. From the results, it is evident that transient water soaking showing significant impact on mechanical strengths. Static and dynamic behaviours do not have much notable change in their nature. The natural frequencies of distilled water aged composite do not have many variations; the salinity percentage is showing a very slight variation on the natural frequencies.

\section{CONCLUSIONS}

From the research work carried on ageing effect of composite marine propeller structural and model behaviour, the following conclusions were drawn.

- Water ageing caused to water uptake of composite material, the water uptake behavior is followed the Fick's law.

- Glass fibre polymer composites Tensile strength and Modulus decreased with soaking time, there is more reduction in tensile strength than tensile modulus.

- The Finite Element Analysis Results revealed that the ageing of composite marine propeller, the maximum tip displacement increases with increase in soaking time. The elemental stress is doesn't change with ageing duration.

- The free vibrations in first 10 modes reducing very slightly with increase in ageing time.

\section{REFERENCES}

1. D. H. Vardhan, A. Ramesh, and B. C. M. Reddy, "A review on materials used for marine propellers," in Materials Today: Proceedings, 2019, vol. 18, doi: 10.1016/j.matpr.2019.07.418.

2. S. V. Joshi, L. T. Drzal, A. K. Mohanty, and S. Arora, "Are natural fiber composites environmentally superior to glass fiber reinforced composites?," Compos. Part A Appl. Sci. Manuf., vol. 35, no. 3, pp. 371-376, 2004, doi: 10.1016/j.compositesa.2003.09.016.

3. A. R. J. V. B. Dinesh Prabhu; "Experimental Investigation of Mechanical Properties of Glass Experimental Investigation of Mechanical Properties of Glass Fiber / Epoxy Composites With," vol. 8, no. March 2016, pp. 125-134, 2018, doi: 10.17148/IARJSET/ICAME.36.

4. A. Boisseau, P. Davies, and F. Thiebaud, "Sea water ageing of composites for ocean energy conversion systems: Influence of glass fibre type on static behaviour," Appl. Compos. Mater., vol. 19, no. 3-4, pp. 459-473, 2012, doi: 10.1007/s10443-0119219-6.

5. C. Ramesh, J. Stanley, and V. Kumar, "Effects Of Hydrolytic Aging On Glass/Epoxy, Kevlar/Epoxy, And Hybrid (Glass/Kevlar/Epoxy) Composites,” vol. 2, no. 5, pp. 1589-1596, 2013. 
6. L. Calabrese, F. Micelli, M. Corradi, M. A. Aiello, and A. Borri, “Ageing and fatigue combined effects on GFRP Grids," Key Eng. Mater., vol. 747 KEM, pp. 525-532, 2017, doi: 10.4028/www.scientific.net/KEM.747.525.

7. E. P. Gellert and D. M. Turley, "Seawater immersion ageing of glass-fibre reinforced polymer laminates for marine applications,” Compos. Part A Appl. Sci. Manuf., vol. 30, no. 11, pp. 1259-1265, 1999, doi: 10.1016/S1359-835X(99)00037-8.

8. A. Hodzic, J. K. Kim, A. E. Lowe, and Z. H. Stachurski, "The effects of water aging on the interphase region and interlaminar fracture toughness in polymer-glass composites," Compos. Sci. Technol., vol. 64, no. 13-14, pp. 2185-2195, 2004, doi: 10.1016/j.compscitech.2004.03.011.

9. M. L. P. Kishore, "Hydrodynamic Design Structural Analysis and Optimization of Marine Propeller Blade Hydrodynamic Design Structural Analysis and Optimization of Marine Propeller Blade,” National Institute of Technology Rourkela, 2016.

10. B. Epps, “OpenProp v2.4 Theory Document," in OpenProp v2.4 Theory Document, vol. 2.4, 2010, pp. 0-32.

11. Ss. Raj, A. Professor, and H. DrPRavinder Reddy, “Design, Fabrication and Analysis of Composite Marine Propeller,” Int. J. Eng. Technol. Manag. Appl. Sci. www.ijetmas.com, vol. 3, no. September 2015, pp. 2349-4476, 2015.

12. Y. . S. Rao and B. S. Reddy, "Harmonic Analysis of Composite Propeller for Marine Applications," Int. J. Res. Eng. Technol., pp. 257-260, 2012.

13. B. G. Paik et al., "Investigation on the performance characteristics of the flexible propellers," Ocean Eng., vol. 73, pp. 139148, 2013, doi: 10.1016/j.oceaneng.2013.09.005.

14. P. Maljaars, M. Kaminski, and H. den Besten, "Boundary Element Modelling Aspects for the Hydro-Elastic Analysis of Flexible Marine Propellers,” J. Mar. Sci. Eng., vol. 6, no. 2, p. 67, 2018, doi: 10.3390/jmse6020067.

15. M.L.Pavan Kishore, R.K.Behera, and S. Bezawada, "Structural Analysis of NAB Propeller Replaced With Composite Material,” Int. J. Mod. Eng. Res., vol. 3, no. 1, pp. 401-405, 2013.

16. M.L.Pavan Kishore, "Free Vibration Analysis of Four Parameter," Proc. 4th SARC Int. Conf., vol. 36, no. 2, pp. 88-91, 2014.

17. M.L.Pavan Kishore, "Harmonic Analysis of Nab Propeller Replaced with Composite Material," Int. J. Curr. Eng. Technol., vol. 4, no. 2, pp. 590-593, 2014.

18. D. H. Vardhan, A. Ramesh, and B. C. Mohana, "Materials Today: Proceedings Effect of ceramic fillers on flexural strength of the GFRP composite material," Mater. Today Proc., no. xxxx, 2020, doi: 10.1016/j.matpr.2020.07.356.

19. V. Sivabharathi, G. S. Chidambaram, N. Sadayan, and S. Ashokraj, "Enhanced mechanical properties of glass fibrereinforced polymer composites with addition of AL2O3,” Aust. J. Mech. Eng., vol. 00, no. 00, pp. 1-9, 2019, doi: 10.1080/14484846.2019.1681848.

20. D. H. Vardhan, A. Ramesh, and B. C. M. Reddy, "Open Water Characteristics and Free Vibration Analysis of Actual and Scaled Marine Propeller,” vol. 29, no. 10, pp. 8262-8273, 2020.

21. N. Tual, N. Carrere, P. Davies, T. Bonnemains, and E. Lolive, "Characterization of sea water ageing effects on mechanical properties of carbon/epoxy composites for tidal turbine blades,” Compos. Part A Appl. Sci. Manuf., vol. 78, pp. 380-389, 2015, doi: 10.1016/j.compositesa.2015.08.035.

22. K. Küçük, "Effect of Seawater on Ageing of Polyester Composites and Study of Aged Composite Polymer," no. February, pp. 1-60, 2017. 
23. R. N. Manjunath, V. Khatkar, and B. K. Behera, "Investigation on Seawater Ageing of PET-Epoxy Composites: An Ecological and Sustainable Approach for Marine Applications," J. Polym. Environ., vol. 28, no. 8, pp. 2289-2300, 2020, doi: 10.1007/s10924-020-01771-2.

24. M. Assarar, D. Scida, A. El Mahi, C. Poilâne, and R. Ayad, "Influence of water ageing on mechanical properties and damage events of two reinforced composite materials: Flax - fibres and glass - fibres,” Mater. Des., vol. 32, no. 2, pp. 788-795, 2011, doi: 10.1016/j.matdes.2010.07.024.

25. K. Liao, C. R. Schultheisz, and D. L. Hunston, "Effects of environmental aging on the properties of pultruded GFRP," Compos. Part B Eng., vol. 30, no. 5, pp. 485-493, 1999, doi: 10.1016/S1359-8368(99)00013-X.

26. A. Komorek, P. Przybytek, and W. Kucharczyk, "Effect of sea water and natural ageing on residual strength of epoxy laminates, reinforced with glass and carbon woven fabrics," Adv. Mater. Sci. Eng., vol. 2016, 2016, doi: $10.1155 / 2016 / 3754912$.

27. E. José-Trujillo, C. Rubio-González, and J. A. Rodríguez-González, "Seawater ageing effect on the mechanical properties of composites with different fiber and matrix types," J. Compos. Mater., vol. 53, no. 23, pp. 3229-3241, 2019, doi: 10.1177/0021998318811514.

28. J. Mercier, A. Bunsell, P. Castaing, and J. Renard, "Characterisation and modelling of aging of composites," Compos. Part A Appl. Sci. Manuf., vol. 39, no. 2, pp. 428-438, 2008, doi: 10.1016/j.compositesa.2007.08.015.

29. E. Poodts, G. Minak, and A. Zucchelli, "Impact of sea-water on the quasi static and fatigue flexural properties of GFRP," Compos. Struct., vol. 97, pp. 222-230, 2013, doi: 10.1016/j.compstruct.2012.10.021.

30. S. Kumarasamy, N. M. Mazlan, M. S. Z. Abidin, and A. Anjang, "Influence of Fuel Absorption on the Mechanical Properties of Glass-Fiber-Reinforced Epoxy Laminates,” J. King Saud Univ. - Eng. Sci., no. xxxx, 2019, doi: 10.1016/j.jksues.2019.09.002.

31. A. Le Guen-Geffroy, P. Y. Le Gac, M. Diakhate, B. Habert, and P. Davies, "Long-term durability of CFRP under fatigue loading for marine applications," MATEC Web Conf., vol. 165, pp. 1-8, 2018, doi: 10.1051/matecconf/201816507001.

32. X. Zhang, Y. Hong, W. Liu, F. Yang, and R. Wang, "Improving the propulsion performance of composite propellers under offdesign conditions," Appl. Ocean Res., vol. 100, no. May, p. 102164, 2020, doi: 10.1016/j.apor.2020.102164.

33. H. Lee, M. C. Song, S. Han, B. J. Chang, and J. C. Suh, "Hydro-elastic aspects of a composite marine propeller in accordance with ply lamination methods,” J. Mar. Sci. Technol., vol. 22, no. 3, pp. 479-493, 2017, doi: 10.1007/s00773-016-0428-4.

34. T. Taketani, K. Kimura, S. Ando, and K. Yamamoto, "Study on Performance of a Ship Propeller Using a Composite Material," Third Int. Symp. Mar. Propulsors, no. May, pp. 536-541, 2013.

35. K. K. Y. Hara, T. Yamatogi, H. Murayama, K. Uzawa, "Perfomrance Evaluation of Composite Marine Propeller for a Fishing Boat By Fluid-Structure Interaction Analysis," 18th Int. Conf. Compos. Mater., pp. 1-6, 2011. 